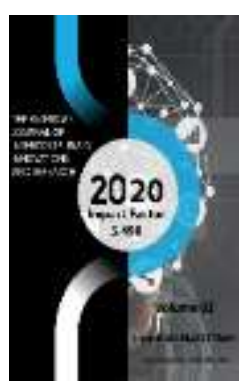

\title{
Mechanisms For The Development Of International Mountain Tourism In The Turkestan Ridge
}

\author{
Matluba Turgunovna Gozieva \\ Principal, Academic lyceum under Jizzakh Polytechnic Institute, Jizzakh, Uzbekistan
}

Journal Website: http://usajournalshub.c om/index,php/tajiir

Copyright: Original content from this work may be used under the terms of the creative commons attributes 4.0 licence.

\section{ABSTRACT}

A comprehensive study of the international mountain tourist facilities of the Turkestan ridge, developed scientific recommendations for use in tourism.

\section{KEYWORDS}

Turkestan ridge, international mountain tourism, foreign tourists, recreational resources, tourist route, nature-population-tourism.

\section{INTRODUCTION}

At present, the tourism industry is becoming a wide-ranging industry. International mountain tourism, which is one of the directions of tourism in Uzbekistan, is also developing rapidly. Therefore, in parallel with the creation of the material and technical base for the development of international mountain tourism, it is necessary to develop a scientific and theoretical basis.
According to industry experts, for mountain vacationers, the most comfortable conditions for a comfortable temperature and the repetition of sunny days occur at altitudes of $1400 \mathrm{~m}$ to $3000 \mathrm{~m}$. However, the rich tourist and recreational resources in the mountainous areas of Uzbekistan are not used in practice. This is due to the lack of tourist bases and 
hotels, insufficient development of transport infrastructure.

Uzbekistan has a rich tourism and recreational potential. Its territory is rich in unique natural and recreational resources, cultural and historical heritage of local and international importance. In Uzbekistan, important international economic, scientific, sports and cultural events are taking place on a regular basis. However, despite the large touristrecreational potential, the opportunities are not used enough. It can be estimated that Uzbekistan can receive 10-15 million foreign tourists a year.

\section{THE MAIN FINDINGS AND RESULTS}

Currently, Uzbekistan is in the process of reforming the tourism sector. Many types of tourism can be developed in the country. Of course, in order to develop new types of tourism, it is necessary to pay timely attention to the world tourism situation.

In the development of international mountain tourism in the mountainous regions of Uzbekistan, it is necessary to develop a "plainmountain" tourist route mechanism for the effective use of existing opportunities (material and technical base - hotels, camping, restaurants, etc.), natural, historical and cultural heritage. It is no secret that currently it is very difficult to build hotels for international tourists in the mountainous regions of Uzbekistan. In the foothills of Samarkand, Urgut, Jizzakh and Tashkent, there are enough hotels for tourists. There are also roads from some mountainous cities to mountainous areas (e.g., from Zaamin to the Turkestan
Mountains, from Gazalkent to the Chimgan Mountains). At the same time, the tourist routes will be directed from the plains to the mountains (exotic landscapes), getting acquainted with historical monuments, oases, artificial hydraulic structures, etc.

The number of tourist attractions will increase as you move from the plains to the mountains. Taking into account the characteristics of vertical landscape zones also plays an important role in the development of mountain tourism.

The need to build resorts in the mountains is also associated with the deterioration of the ecological situation in the plains of the country and the pollution of large cities. In summer, the plains are dominated by hot weather. As a result, the number of people going to the mountains on weekends is constantly increasing. The chaotic nature of the holiday does a lot of damage to the natural environment. Therefore, it is necessary to create recreational bases that are of international importance and meet environmental requirements, as opposed to the constant use of recreational resources.

In the Zominsuv basin of the Turkestan ridge, it is also necessary to place recreation areas in connection with the change of vertical landscape zones. The vertical landscapes of the Zominsuv basin are divided into 4 zones. Natural complexes of tourist significance of each zone were identified and tourist opportunities were assessed (see Table 1). 
The tourist potential of the vertical landscapes of the Zamin basin

\begin{tabular}{|c|c|c|c|}
\hline № & Vertical landscape zones & $\begin{array}{c}\text { Natural complexes } \\
\text { of tourist } \\
\text { importance }\end{array}$ & $\begin{array}{c}\text { Tourist } \\
\text { opportunities }\end{array}$ \\
\hline I & $\begin{array}{l}\text { Mountain Plain and Zominsuv Range } \\
\qquad(450-850 \mathrm{~m})\end{array}$ & $\begin{array}{l}\text { 1. The upper part of } \\
\text { the spread } \\
\text { 2. The edge of the } \\
\text { spread }\end{array}$ & $\begin{array}{l}\text { The city of Zaamin } \\
\text { and its recreation } \\
\text { areas } \\
\text { Agro landscapes }\end{array}$ \\
\hline II & $\begin{array}{l}\text { Low-altitude dry-subtropical zone } \\
\text { with hilly ridges (900-1800 m) }\end{array}$ & $\begin{array}{l}\text { 3. River valleys, } \\
\text { terrace landscapes } \\
\text { 4. Inter-river } \\
\text { watersheds }\end{array}$ & $\begin{array}{l}\text { Short in summer } \\
\text { term leave } \\
\text { Excursion in the } \\
\text { spring }\end{array}$ \\
\hline III & $\begin{array}{l}\text { Average high mountain forest zone } \\
\text { with steep slopes (1800-2000, 2600- } \\
\qquad 2800 \mathrm{~m})\end{array}$ & $\begin{array}{l}\text { 5. Kizilmozor } \\
\text { complex consisting } \\
\text { of pomogen- } \\
\text { neochen lines } \\
\text { 6. Wavy high } \\
\text { mountain plateau } \\
\text { complex }\end{array}$ & $\begin{array}{l}\text { Excursion to the } \\
\text { rock sculptures } \\
\text { "Forty girls". } \\
\text { Travel to the gorge } \\
\text { where } 4 \text { rivers } \\
\text { (Sharillak, Kizilsuv, } \\
\text { Kashkasuv and } \\
\text { Kolsay) join the }\end{array}$ \\
\hline
\end{tabular}




\begin{tabular}{|c|c|c|c|}
\hline & & $\begin{array}{l}\text { 7. Karst incident } \\
\text { curves typical for } \\
\text { rare tropical zones } \\
\text { 8. Chortangi } \\
\text { landscape }\end{array}$ & $\begin{array}{l}\text { world-famous } \\
\text { tourism } \\
\text { opportunities }\end{array}$ \\
\hline IV & $\begin{array}{l}\text { High mountain watershed subalpine } \\
\text { zone }\end{array}$ & $\begin{array}{l}\text { 9. Shahristan and } \\
\text { G'oralash passes } \\
\text { complex } \\
\text { 10. Complex of large } \\
\text { catchment tanks } \\
\text { 11. Giant steep cliffs } \\
\text { (called "Meeting", } \\
\text { "Waiting" and } \\
\text { others) }\end{array}$ & $\begin{array}{l}\text { In the summer, you } \\
\text { can ride on the old } \\
\text { denudation faces in } \\
\text { the car. } \\
\text { Short-term } \\
\text { excursions in } \\
\text { summer. } \\
\text { Excursions to the } \\
\text { rocks called "Wait" } \\
\text { and "Meeting" can } \\
\text { be organized }\end{array}$ \\
\hline
\end{tabular}

Note: prof. L. Alibekov (2013) data, edited by the author.

\section{CONCLUSION}

The natural geographical, economic and social features of the Turkestan ridge, as well as tourist facilities are being studied in a consistent manner. We offer the following suggestions and comments on the optimal options for the development of international mountain tourism in the Turkestan ridge, as well as to solve the problem of maintaining the balance in the triad of "Nature-populationtourism".

- Study and analysis of international mountain tourism in Uzbekistan as an independent direction of tourism;

- A new approach to the development of international mountain tourism, the scientific study of the vertical 
transformation of tourist facilities from the plains to the mountains;

- Increase the number of guides and volunteers in the region, serving international tourists, fluent in English and other foreign languages;

- For the first time a comprehensive study and analysis of tourist facilities in the Turkestan ridge;

- Study and tourist assessment of natural objects in the Turkestan ridge, such as waterfalls, streams, springs, streams, caves, natural stone columns, gorges, centuries-old spruce and walnut;

- Study and tourist assessment of sociohistorical sites located on the territory of the Turkestan ridge, including national bases, national values and crafts of the local population, as well as shrines;

- Development of recommendations for the organization of "ecological trail" routes for international tourists in the Turkestan ridge and the organization of "hotels" for recreation during this route;

- Providing scientific advice to local tourism organizations and firms in the promotion of international mountain tourism (creation of websites, booklets, photo albums, etc.) in the cities of Zaamin and Osmat on the slopes of the Turkestan ridge;

- Development of scientific recommendations for the preparation and movement of schematic route maps of international mountain tourism in the Turkestan ridge;

- Solve the problem of employment of a certain part of the local population (about $50 \%$ ) through the development of international mountain tourism in the Turkestan ridge;

- Along with the development of international mountain tourism in the region, great attention is paid to nature protection. It is necessary to develop recommendations on how to spend a certain part of the income from international mountain tourism (about $40 \%$ in nature protection, as in developed countries.

\section{REFERENCES}

1. Alibekov L.A. Zaamin National Park and the geographical basis for solving geoecological problems. - Tashkent: Science and Technology, 2013.

2. Go'dalov M. R. Nature of Jizzakh region and its protection. - $\mathrm{T}$.: "Science and technology", 2014.

3. Go'dalov M.R., Normatova M. Tourist areas of Jizzakh region. Modern socioeconomic geography: achievements, problems and prospects. - Tashkent: 2013.

4. Rakhmankulova, Z. B., \& Rakhmankulova, M. B. (2019). SOME PECULIARITIES OF THE BOOKBINDING IN TEMURID'S EPOCH. Theoretical \& Applied Science, (10), 266-272.

5. Rahmankulova Z. Ottoman Empire and the political activity of England in Central Asia in the 19 th century. European Society for Central Asian Studies Tenth Conference. Central Asia Sharing Experiences and Prospects. Ankara. 2007.

6. Rahmankulova Z. Rejuvenating silkroad: past present and future of Turkey-Uzbekistan reletions. 1 st edition Istanbul Sabahattin Zaim university publications. - Turkey. 2019. - pp. $185-186$

7. Rahmokulova Z. Birinci dunya savasi ve Turkistan. Uluslararasi Asya ve Africa 
calismalari kongresi. 38.ICANAS (bildiri ozetleri). Ankara. 2007. p.304

8. Omonov, Q., \& Karimov, N. (2020). Importance Of Ancestoral Heritage. The American Journal of Social Science and Education Innovations, 2(09), 196202.

9. Rasuljanovna, I. N., \& Rakhmonqulovich, K. N. (2020). Trade Relations Between Ancient Bacteria And China On The II-I BC. The American Journal of Social Science and Education Innovations, 2(07), 47-51. 